\title{
The effect of regulated deficit irrigation on growth, yield, and berry quality of grapevines (cv. Sangiovese) grafted on rootstocks with different resistance to water deficit
}

\author{
Giovanni Caruso $^{1} \cdot$ Giacomo Palai $^{1}$ (I) $\cdot$ Riccardo Gucci $^{1} \cdot$ Claudio D'Onofrio $^{1}$
}

Received: 20 September 2021 / Accepted: 20 January 2022

(c) The Author(s) 2022

\begin{abstract}
The aim of this work was to investigate the effect of full irrigation (FI), pre-veraison water deficit (RDI 1), or post-veraison water deficit (RDI 2) on growth, yield, and berry quality in container-grown, mature vines of cv. Sangiovese grafted onto either 1103P or SO4 rootstock over two consecutive growing seasons. Deficit irrigation regimes significantly affected vine water status of both rootstocks before and after veraison. Trunk diameter (TD) increment was markedly affected when water was restricted early, but not in the post-veraison period. Deficit irrigation from fruit set to veraison inhibited vegetative growth (TD, canopy volume, and weight of pruned wood) more than that applied from veraison to harvest. Yield was unaffected by either irrigation or rootstock in both years. Irrigation had a marked effect on berry and juice quality: the RDI 1 treatment induced the highest berry anthocyanin concentration, and the lowest titratable acidity (TA), which, instead, increased in the RDI 2 treatment. RDI treatments did not modify berry dry weight, soluble solid content, TA, anthocyanins, and epicarp total phenols in vines on both rootstocks.
\end{abstract}

\section{Introduction}

Productivity and berry quality of Vitis vinifera L., a moderately drought resistant species, change in response to soil water availability during the growing season (Chaves et al. 2010; Girona et al. 2009; Intrigliolo et al. 2016; Romero et al. 2010). The most important physiological effects of water deficit on plants include: (i) lower rates of stomatal conductance and photosynthesis (De Souza et al. 2003; Iacono et al. 1998; Koundouras et al. 2008; Palliotti et al. 2014; Torres et al. 2021); (ii) less internode elongation and plant leaf area development (Lovisolo et al. 2010; Lovisolo and Schubert 1998; McDowell 2011; Schultz and Matthews 1988); (iii) lower fruit yield; (iv) changes in berry and wine quality (Chaves et al. 2010; Chaves and Oliveira 2004; Dos Santos et al. 2003; Intrigliolo et al. 2016; Romero et al. 2010).

While water deficit is more effective in reducing vegetative growth than fruit growth (Dry and Loveys 1998;

Giacomo Palai

giacomo.palai@phd.unipi.it

1 Department of Agriculture Food and Environment, University of Pisa, Pisa, Italy
Williams et al. 1994), vine performance depends not only on total available water, but also on the phenological stage at which water scarcity develops and this effect is mediated by the genotype. Palliotti et al. (2014) reported that water stress applied from fruit set until veraison induced a reduction in internode diameter and length in two cultivars compared to well-watered vines but, while the yieldto-pruning weight ratio was unaffected by water deficit in cv. Sangiovese, it increased in cv. Montepulciano by $21 \%$. Differences in gas exchange responses to water availability between cvs. Sangiovese and Montepulciano have also been reported (Tombesi et al. 2014).

The timing of drought events during the growing season has a strong impact on grape yield (Girona et al. 2009; Intrigliolo et al. 2016; Lanari et al. 2014; Munitz et al. 2017). Final berry size and yield are more affected when drought occurs early during the growing season than after veraison. Early water limitations reduce berry cell divisions, which inhibit berry size from full recover even after optimal soil humidity is restored later in the growing season (Chaves et al. 2010; Coombe and McCarthy 2000; Ojeda et al. 1999). Berry transpiration is the primary route for water loss throughout berry development and veraison appears to be the turning point for changes in water supply to the 
berry, which occurs mainly via the phloem after veraison (Greenspan et al. 1994; Rogiers et al. 2001).

Berry quality parameters vary depending on the extent and timing of water deficit (Dry and Loveys 1998; Jackson and Lombard 1993). Early water stress has been reported to exert a positive effect on berry quality through a reduction in crop level, berry size, and canopy vigour (Dry et al. 2001). Girona et al. (2009) reported that an increasing level of water stress applied between fruit set and veraison in potted vines of cv. Tempranillo determined a linear decrease in soluble solids content (SSC) and a slight increase in the titratable acidity (TA) of the must. A similar effect of early water stress on SSC was also apparent in Sangiovese and Montepulciano potted vines, whereas water deficit did not affect TA and $\mathrm{pH}$ (Palliotti et al. 2014). Previous studies carried out on cultivars Cabernet Sauvignon and Tempranillo reported higher concentration of anthocyanins in berries from grapevine subjected to early water deficit with respect to those sampled from fully irrigated ones (Castellarin et al. 2007; Intrigliolo and Castel 2010). Post-veraison water stress has been associated with an increase in SSC due to dehydration and a concentration effect on berry solutes, whereas TA and pH were unaffected (Basile et al. 2011; Intrigliolo et al. 2016).

Although originally selected to confer resistance to phylloxera aphids, rootstocks are important in maintaining vineyard performance when abiotic stresses, such as drought, flooding, salinity, or excessive lime, occur (Carbonneau 1985; Howell 1987) as they can influence water uptake, drought resistance, and vine vigour. Different mechanisms have been proposed to explain: i) how rootstocks affect scion water relations and transport (Alsina et al. 2011; Carbonneau 1985; Cuneo et al. 2021; Soar et al. 2006; Tramontini et al. 2013); ii) hormonal and hydraulic signalling (Loveys and Kriedemann 1974; Soar et al. 2006; Stoll et al. 2000); iii) vegetative growth, berry development and quality (Koundouras et al. 2008, 2009). The rootstock-scion interaction often influences vine growth and performance (Tramontini et al. 2013; Romero et al. 2019), yet direct rootstock effects on berry quality can be rather difficult to separate from those caused by rootstock-induced vigour and rapid depletion of soil moisture. Koundouras et al. (2009) reported a significant effect of rootstock and irrigation treatments on seeds flavan-3-ols of berries sampled from Cabernet Sauvignon grapevines grafted on $1103 \mathrm{P}$ and SO4. The same authors attributed this result to differences in canopy size and microclimate conditions induced by rootstocks. In a study carried out on Chardonnay, Merlot, and Syrah grapevines grafted on five different rootstocks (5C, 140Ru, 1103P, 3309C, 101CU, and own-rooted) and subjected to water deficit, Keller et al. (2012) reported a significant rootstock effect only on must $\mathrm{pH}$, whereas anthocyanins and tannins concentrations were unaffected. Merli et al. (2016) tested the new drought-tolerant rootstock (M4) against SO4 on Sangiovese grapevines. They reported that berries sampled from waterstressed grapevines grafted on M4 showed the highest SSC and anthocyanins values, suggesting a potential role of the rootstock in triggering gene regulation under water stress conditions.

Previous studies focusing on irrigation and/or rootstock effects on water relations, vegetative growth, yield, and berry composition consisted of short (3-7 weeks) dryingdown cycles in young (1- or 2-year-old) potted vines over one or two growing seasons (Basile et al. 2011; Girona et al. 2009; Meggio et al. 2014). In other cases, either non-fruiting plants were used (Galbignani et al. 2016; Lanari et al. 2015) or only physiological parameters and vegetative growth were measured. A few experiments to date have compared the performance of mature vines grafted on different rootstocks under different levels of water availability (Romero et al 2018, 2019; Koundouras et al. 2008; Merli et al. 2016).

The present study was conducted to investigate the effects of long-term irrigation regimes (full irrigation, pre-veraison water deficit, and post-veraison water deficit) on vine growth, yield, and grape quality in potted, mature vines of cv. Sangiovese grafted onto two rootstocks differing in their drought resistance over 2 consecutive years. Sangiovese is the most widely grown cultivar in Italy and it is considered to be drought-tolerant (Palliotti et al. 2014). The 1103 Paulsen and SO4 rootstocks can be classified as tolerant and sensitive to water stress, respectively, despite some discrepancies in the extent of resistance reported by different authors (Carbonneau 1985; Howell 1987).

\section{Materials and methods}

\section{Plant material and experimental conditions}

In 2018, a 2-year experiment was started on 6-year-old grapevines (Vitis vinifera L.) of cultivar Sangiovese grafted on two rootstocks [1103 Paulsen (V. rupestris $\mathrm{x} V$. berland$i e r i)$ and Selection Oppenheim $4(\mathrm{SO} 4)(V$. riparia $\times V$. berlandieri)] grown in $50 \mathrm{~L}$ containers (40\% peat and $60 \%$ silty-loam soil) at the Colignola experimental farm of the Department of Agriculture Food and Environment of the University of Pisa $\left(43.73^{\circ} \mathrm{N} 10.47^{\circ} \mathrm{E}, 5 \mathrm{~m}\right.$ a.s.1.). Vines were grown outdoor and spaced at $4.2 \times 0.9 \mathrm{~m}$ distance to allow high light interception. Vines were pruned in February to retain one spur with two count buds and one cane with 6-8 count buds according to the Guyot training system. Growing shoots were positioned vertically using a trellis system made of seven horizontal galvanized steel wires running along each row of containers at three different heights. The containers were covered with plastic film to minimize soil water evaporation. 
Climatic conditions over the study period were monitored using a weather station WatchDog (Spectrum Technologies Inc, Aurora IL, USA) installed on site. Growing degree days (GDD) were calculated by summing daily mean temperatures greater than $10^{\circ} \mathrm{C}$ from April 1 to October 31. Starting from 2 weeks before bud burst, vine phenology was monitored every 4-5 days to determine the dates of bud burst (4 E-L), fruit set (27 E-L) and veraison (34 E-L), using the modified Eichhorn-Lorenz (E-L) scale (Coombe 1995). Annual precipitation was 934 and $970 \mathrm{~mm}$ in 2018 and 2019, respectively, whereas potential evapotranspiration $\left(\mathrm{ET}_{0}\right)$, calculated according to the Penman-Monteith equation, was 927 and $900 \mathrm{~mm}$ in those same years (Table 1). Climatic conditions during the first 5 months of the year were quite different between 2018 and 2019. In particular, mean air temperature of April-May was lower in $2019\left(14.7^{\circ} \mathrm{C}\right)$ than in $2018\left(17.5^{\circ} \mathrm{C}\right)$. During the summer months (June, July, August, and September), the mean air temperature was similar (23.4 and $23.5^{\circ} \mathrm{C}$ in 2018 and 2019 , respectively), but rainfall was different $(140 \mathrm{~mm}$ in 2018 and $183 \mathrm{~mm}$ in 2019).

\section{Irrigation}

All vines were fully irrigated until day of the year (DOY) 154 (2018) and 164 (2019) when three different irrigation regimes (Full Irrigation, FI; Regulated Deficit Irrigation 1, RDI 1; Regulated Deficit Irrigation 2, RDI 2) were imposed on both rootstocks. Fully irrigated vines received water from budburst to harvest, whereas RDI 1 and RDI 2 vines were subjected to water deficit (34-49\% of full irrigation) from fruit set to veraison (FS-V) and from veraison to harvest $(\mathrm{V}-\mathrm{H})$, respectively (Table 2 ). All vines were fully irrigated when water deficit was not imposed and from harvest until leaf fall. Each container received water from two emitters $\left(2 \mathrm{~L} \mathrm{~h}^{-1}\right.$ each) and vines were irrigated twice a day. In the second year of the experiment, RDI 1 vines were replaced with new ones to prevent potential effects on bud fertility of early water stress undergone in the first year.

In both years, FI vines were irrigated to maintain stem water potential $\left(\Psi_{\text {stem }}\right)$ values above $-0.6 \mathrm{MPa}$; in 2019 , water volumes were also adjusted based on actual water consumption of FI vines, measured as daily weight loss of four representative vines. Vines were placed on four square weighing platforms with load cells placed in every corner and their weight loss measured at 15 min intervals. The top surface of the pots was sealed around the trunk with plastic film to avoid evaporation from the soil, and the transpirative component (T) of evapotranspiration (ET) determined. Vines were daily irrigated with a volume of water exceeding (about 10-15\%) the water consumption of the previous day. The maximum grapevine daily transpiration was calculated according to

$E_{\max }=I-D-\Delta W$, where $I$ was the irrigation volume, $D$ drainage, and $\Delta W$ the change in soil water. In 2019, the daily values of maximum transpiration $\left(E_{\max }\right)$ were plotted against $E T_{0}$ values and a correction coefficient (CF) calculated as $\mathrm{CF}=E_{\max } / E T_{0}$. Average monthly values of $\mathrm{CF}$ were $0.5,0.9,1.1$, and 0.8 in June, July, August, and September, respectively.

\section{Vine water status}

Vine water status was determined by measuring $\Psi_{\text {stem }}$ during the growing season at 7-10 day intervals starting from DOY 150 and DOY 161 in 2018 and 2019, respectively. The leaf

Table 1 Monthly values of precipitation $(P)$, mean air temperature ( $T$ ), growing degree days (GDD), vapor pressure deficit (VPD), and reference evapotranspiration $\left(E T_{0}\right)$ measured in 2018 and 2019 using a weather station installed on site

\begin{tabular}{|c|c|c|c|c|c|c|c|c|c|c|}
\hline \multirow[t]{2}{*}{ Month } & \multicolumn{5}{|l|}{2018} & \multicolumn{5}{|l|}{2019} \\
\hline & $\begin{array}{l}P \\
(\mathrm{~mm})\end{array}$ & $\begin{array}{l}T \\
\left({ }^{\circ} \mathrm{C}\right)\end{array}$ & $\begin{array}{l}\text { Monthly } \\
\text { GDD }\left({ }^{\circ} \mathrm{C}\right)\end{array}$ & $\mathrm{VPD}(\mathrm{kPa})$ & $E T_{0}(\mathrm{~mm})$ & $\begin{array}{l}P \\
(\mathrm{~mm})\end{array}$ & $\begin{array}{l}T \\
\left({ }^{\circ} \mathrm{C}\right)\end{array}$ & $\begin{array}{l}\text { Monthly } \\
\text { GDD }\left({ }^{\circ} \mathrm{C}\right)\end{array}$ & $\mathrm{VPD}(\mathrm{kPa})$ & $E T_{0}(\mathrm{~mm})$ \\
\hline January & 48 & 10.3 & & 0.5 & 0.8 & 46 & 6.2 & & 0.4 & 0.7 \\
\hline February & 95 & 6.6 & & 0.3 & 1.0 & 50 & 9.4 & & 0.5 & 1.2 \\
\hline March & 208 & 10.0 & & 0.5 & 1.7 & 10 & 11.9 & & 0.6 & 1.9 \\
\hline April & 71 & 16.2 & 185.0 & 0.9 & 3.0 & 109 & 13.7 & 111.8 & 0.7 & 2.8 \\
\hline May & 107 & 18.8 & 272.6 & 1.0 & 3.6 & 116 & 15.6 & 174.1 & 0.7 & 3.2 \\
\hline June & 17 & 22.2 & 361.2 & 1.4 & 4.6 & 4 & 23.1 & 390.7 & 1.6 & 4.9 \\
\hline July & 48 & 24.8 & 463.1 & 1.5 & 4.9 & 123 & 25.0 & 467.7 & 1.7 & 4.8 \\
\hline August & 13 & 25.2 & 480.4 & 1.8 & 4.2 & 18 & 24.7 & 468.5 & 1.7 & 4.2 \\
\hline September & 62 & 21.4 & 353.1 & 1.5 & 3.1 & 38 & 21.3 & 346.2 & 1.4 & 2.9 \\
\hline October & 82 & 18.2 & 253.6 & 1.0 & 1.9 & 104 & 17.5 & 249.0 & 0.9 & 1.5 \\
\hline November & 99 & 13.0 & & 0.6 & 1.0 & 328 & 13.2 & & 0.5 & 0.9 \\
\hline December & 84 & 8.8 & & 0.4 & 0.7 & 24 & 9.8 & & 0.5 & 0.6 \\
\hline
\end{tabular}


Table 2 Dates of veraison and harvest, and irrigation volumes of grapevines (cv. Sangiovese) for $1103 \mathrm{P}$ and SO4 rootstocks in 2018 and 2019

\begin{tabular}{|c|c|c|c|c|c|c|c|}
\hline \multirow[t]{2}{*}{ Year } & \multirow[t]{2}{*}{ Rootstock } & \multirow[t]{2}{*}{ Irrigation } & \multirow{2}{*}{$\begin{array}{l}\text { Veraison } \\
\text { (DOY) }\end{array}$} & \multirow{2}{*}{$\begin{array}{l}\text { Harvest } \\
\text { (DOY) }\end{array}$} & \multicolumn{3}{|c|}{ Irrigation volumes $\left(\mathrm{L}\right.$ vine $\left.\mathrm{e}^{-1}\right)$} \\
\hline & & & & & FS-V & $\mathrm{V}-\mathrm{H}$ & FS-H \\
\hline \multirow[t]{6}{*}{2018} & \multirow[t]{3}{*}{$1103 \mathrm{P}$} & FI & 206 & 263 & 178 & 276 & 454 \\
\hline & & RDI 1 & 208 & 263 & $63(35)$ & 272 & $335(74)$ \\
\hline & & RDI 2 & 206 & 240 & 178 & $137(50)$ & $315(69)$ \\
\hline & \multirow[t]{3}{*}{ SO4 } & FI & 200 & 264 & 152 & 302 & 454 \\
\hline & & RDI 1 & 197 & 264 & $52(34)$ & 320 & $372(82)$ \\
\hline & & RDI 2 & 200 & 240 & 152 & $145(48)$ & $297(66)$ \\
\hline \multirow[t]{6}{*}{2019} & \multirow[t]{3}{*}{$1103 \mathrm{P}$} & FI & 213 & 277 & 211 & 204 & 415 \\
\hline & & RDI 1 & 218 & 262 & $77(36)$ & 185 & $262(63)$ \\
\hline & & RDI 2 & 213 & 253 & 211 & $86(42)$ & $297(72)$ \\
\hline & \multirow[t]{3}{*}{$\mathrm{SO} 4$} & FI & 213 & 277 & 211 & 204 & 415 \\
\hline & & RDI 1 & 213 & 276 & $69(33)$ & 204 & $273(66)$ \\
\hline & & RDI 2 & 213 & 262 & 211 & $86(42)$ & $297(72)$ \\
\hline
\end{tabular}

In brackets, the percentage of irrigation volume applied to RDI vines with respect to fully irrigated ones (FI) of the same rootstock

$D O Y$ day of the year, $F S-V$ fruit set-veraison, $V-H$ veraison-harvest was enclosed for at least $60 \mathrm{~min}$ in a non-transpiring shaded bag to block transpiration and then sampled to determine $\Psi_{\text {stem }}$ once the potential reached equilibrium with the xylem according to methods reported by Shackel (2011). Stem water potential was measured on three vines per treatment (one leaf per vine) between 12:00 and 1:00 p.m. Leaves were excised with a razor blade and immediately put in the chamber cylinder (PMS Instruments, Albany, OR, USA), which was then pressurized with nitrogen gas. Fluctuations in vine water status during the irrigation period were accounted for by calculating the water stress integral (WSI) as reported by Myers (1988).

\section{Vegetative growth}

In both years, after harvest, the total length of the proximal, median, and distal main shoots borne on each vine was measured, as well as the total number of nodes per shoot and internode length determined. At the end of February, the pruning weight of three vines was measured to calculate the yield to-pruning weight ratio. The rootstock trunk diameter was measured eight times in 2018 from budburst to harvest, taking two measurements (minimum and maximum) per vine.

In 2018, vine canopy volume was measured manually at the beginning of the irrigation differentiation (Caruso et al. 2017). In 2019, canopy volume was measured seven times from the beginning of irrigation differentiation to harvest using aerial images and the structure from motion technique (Caruso et al. 2017). Images were acquired from a multispectral camera (Micasense RedEdge MX, MicaSense Inc.) carried by an unmanned aerial vehicle (UAV) flying autonomously over a predetermined waypoint course at $50 \mathrm{~m}$ above ground level. The three-dimensional canopy volume was reconstructed starting from the digital surface model (DSM) obtained using Agisoft Photo-Scan ${ }^{\circledR}$ (Agisoft LLC) which was then processed using a GIS software (ArcGIS software $^{\circledR}$, ESRI, Redlands, CA, USA), as in Caruso et al. (2017).

\section{Yield and berry characteristics}

Harvest dates were established based on monitoring of solid soluble content (SSC) in the berry. In particular, grapes were harvested between DOY 240 (August 28) and 264 (September 21) in 2018 and between DOY 253 (September 10) and 277 (October 4) in 2019 when soluble solid accumulation had reached $22 \pm 0.5^{\circ}$ Brix (Table 2). Bunches were harvested from single vines and crop weight per vine and berry fresh weight immediately determined. Berry dry weight was measured after oven-drying at $70{ }^{\circ} \mathrm{C}$ until constant weight. The stage of ripening was expressed as the number of days before the last date of harvest (control vines) across all treatments within each year (see also Fig. 4).

Total SSC, TA, and $\mathrm{pH}$ were determined on samples of 20 berries for each rootstock-irrigation combination (three 20-berry replicates per treatment). The berry juice was extracted from each sample, SSC measured with a hand refractometer, and a $10 \mathrm{~mL}$ aliquot titrated with $0.1 \mathrm{~N} \mathrm{NaOH}$ to an endpoint $\mathrm{pH}$ of 8.2 to determine $\mathrm{TA}\left(\mathrm{g} \mathrm{mL}^{-1}\right)$. The $\mathrm{pH}$ was measured with a $\mathrm{pH}$ meter (Hanna Instruments, Woonsocket RI, USA) calibrated at pH 7.0 and 4.0.

At harvest, 50 berries from three vines per treatment were used for the determination of anthocyanins (epicarp), flavonoids (epicarp and seeds), and total phenols (epicarp and seeds) according to the method by Di Stefano et al. (1989), 
modified as follows. The epicarp were manually separated from mesocarp and seeds, and weighed and extracted for $4 \mathrm{~h}$ at room temperature in $25 \mathrm{~mL}$ of a $\mathrm{pH} 3.2$ tartaric buffer solution ( $12 \% \mathrm{v} / \mathrm{v}$ ethanol, $2 \mathrm{~g} / \mathrm{L}$ sodium metabisulphite, $5 \mathrm{~g} / \mathrm{L}$ tartaric acid, and $22 \mathrm{~mL} / \mathrm{L} \mathrm{NaOH} 1 \mathrm{~N}$ ). After homogenization using an immersion blender (Ultra-Turrax IKA, Staufen, Germany), the extract was separated by centrifugation for $5 \mathrm{~min}$ at $1006 \times \mathrm{g}$, and then, the pellet was re-suspended in $20 \mathrm{~mL}$ of buffer and centrifuged for $5 \mathrm{~min}$. The final two pooled supernatants were adjusted to $50 \mathrm{~mL}$ with the buffer solution. Anthocyanins were measured on the extract using a UV-Vis spectrophotometer (Hitachi U-2000, Tokyo, Japan) at $540 \mathrm{~nm}$ after 1:20 dilution with ethanol chloride. Total phenols in the epicarp and seeds extracts were measured after 1:10 dilution, using Folin-Ciocalteu reagent with sodium carbonate in water, and read at $750 \mathrm{~nm}$, flavonoids on the 1:20 and 1:50 diluted extract (skin and seeds, respectively) with ethanol chloride at $280 \mathrm{~nm}$. The absorbance was then adjusted using the spectrum obtained between 230 and $350 \mathrm{~nm}$, which identify the value intercepted from the tangent passing through the lower values of the peak at $280 \mathrm{~nm}$ and its parallel to the ordinate axis. Anthocyanins were expressed as milligram of equivalents of malvidin 3-O-glucoside, flavonoids, and phenolic compounds as milligram of equivalents of $(+)-$ catechin.

\section{Experimental design and statistical analysis}

Grapevines were arranged according to a split-plot design with rootstock (R) as the main plot and irrigation regime (I) as the subplot. Twenty-four vines for each rootstock were subjected to three different irrigation treatments (eight vines per treatment). A total of six rootstock-irrigation combinations were thus investigated in this experiment. Stem water potential and berry weight were measured on three representative vines per treatment, whereas all other parameters on five vines. Data were analysed via two-way ANOVA for a split-plot design using CoStat software (CoHort software, Monterey, CA, USA). The Principal Component Analysis (PCA) was performed using JMP 13 (JMP SAS, Campus Drive Cary, NC, USA) and datasets which included the grapevine vegetative parameters, water status, and berry quality parameters ( 2 years, two rootstocks, three irrigation treatments, and three biological replicates).

\section{Results}

\section{Phenology}

The low temperatures measured in May 2019 caused a delay in fruit set of vines (DOY 164 when 390 GDD had been accumulated) with respect to 2018 (DOY 154 equivalent to
394 GDD). The dates of veraison and harvest (average of all treatments) in 2019 were delayed by 10 and 12 days, respectively, compared to 2018 (Table 2). In 2018, the 1103P rootstock induced a delay in veraison date of 6 (FI and RDI 2), and 11 (RDI 1) days with respect to vines grafted on SO4, whereas in 2019, the date of veraison of RDI 1 only vines was delayed 5 days (Table 2). In 2018, the harvest date of vines that had been subjected to post-veraison deficit irrigation occurred 23 and 24 days earlier than other irrigation treatments for 1103P and SO4, respectively; in 2019, the harvest date for RDI 2 was 24 and 15 days earlier than that for the FI treatment for those respective rootstocks (Table 2). As a result, in 2018, the V-H interval lasted 55-57 days for RDI 1 and FI vines grafted on 1103P, but only 34 for RDI 2 ones (Table 2); similarly the V-H interval lasted 64-67 days for FI and RDI 1 treatments and only 40 for RDI 2-treated vines on SO4 rootstock. In 2019, the $\mathrm{V}-\mathrm{H}$ period was 40 , 44, and 64 days for RDI 2, RDI 1, and FI vines on 1103P, respectively $(49,63$, and 64 days for vines on SO4).

\section{Vine water status}

The $\Psi_{\text {stem }}$ of FI vines ranged from -0.29 to $-0.60 \mathrm{MPa}$ in 2018 and from -0.25 to $-0.52 \mathrm{MPa}$ in 2019 , with the exception of two dates when $\Psi_{\text {stem }}$ dropped to -1.0 (DOI 218 in 2018) and - 0.7 MPa (DOY 175 in 2019) due to pump failure (Fig. 1). The seasonal course of $\Psi_{\text {stem }}$ values closely followed the amount of water supplied by irrigation without differences between rootstocks in both years (Fig. 1; Table 2). A significant reduction in $\Psi_{\text {stem }}$ was measured 8 (DOY 162) and 18 (DOY 182) days after the beginning of the RDI 1 regime in 2018 and 2019, respectively (Fig. 1C, D). In both years, the lowest values of $\Psi_{\text {stem }}$ measured before veraison were those of RDI 1 vines grafted on 1103P. The $R$ $\times$ I interaction for $\Psi_{\text {stem }}$ was significant at six and three dates in 2018 and 2019, respectively (Fig. 1).

Differences in $\Psi_{\text {stem }}$ were reflected in the WSI values for respective treatments. The lowest values of daily WSI were reached by RDI 1 vines in 2018 and RDI 2 ones in 2019. In 2018 , WSI values at harvest for 1103P were 24.1, 77.3, and $44.3 \mathrm{MPa} \cdot$ day for FI, RDI 1, and RDI 2, respectively (for SO4 23.2, 45.4, and 51.3 MPa - day); in 2019, WSI values at harvest were 20.1, 58.4, and 69.4 for 1103P (for SO4 $21.2,56.3$, and $66.5 \mathrm{MPa} \cdot$ day) for those respective treatments. Significant differences between rootstocks in daily WSI within the same irrigation treatment, calculated for the period comprised between fruit set and veraison, were measured for RDI 1 vines in 2018 (-1.08 and $-0.73 \mathrm{MPa} \cdot$ day for $1103 \mathrm{P}$ and SO4, respectively). In 2018, the lower values of daily WSI in 1103P vines (RDI 1 treatment) over the entire FS-H period were due in part to a longer period of water stress (veraison occurred 11 days after than in SO4). However, considering the same date of veraison (DOY 197) for 
Fig. 1 Seasonal course of stem water potential $\left(\Psi_{\text {stem }}\right)$ measured in 2018 (A, C, E) and 2019

$(\mathbf{B}, \mathbf{D}, \mathbf{F})$ in grapevines (cv. Sangiovese) grafted on 1103P or $\mathrm{SO} 4$ rootstock and subjected to different irrigation regimes (FI, full irrigation; RDI 1, water deficit applied from fruit set to veraison; and RDI 2, water deficit from veraison to harvest). Values are means \pm standard error of three vines per treatment. Asterisks in top insert indicate significant effects for rootstock (R), irrigation (I), and $\mathrm{R} \times \mathrm{I}$ interaction, calculated after ANOVA $(p<0.05)$ for a split-plot design (R main factor, I sub-factor). Solid (SO4) and dotted (1103P) vertical lines indicate the date of veraison within each irrigation treatment

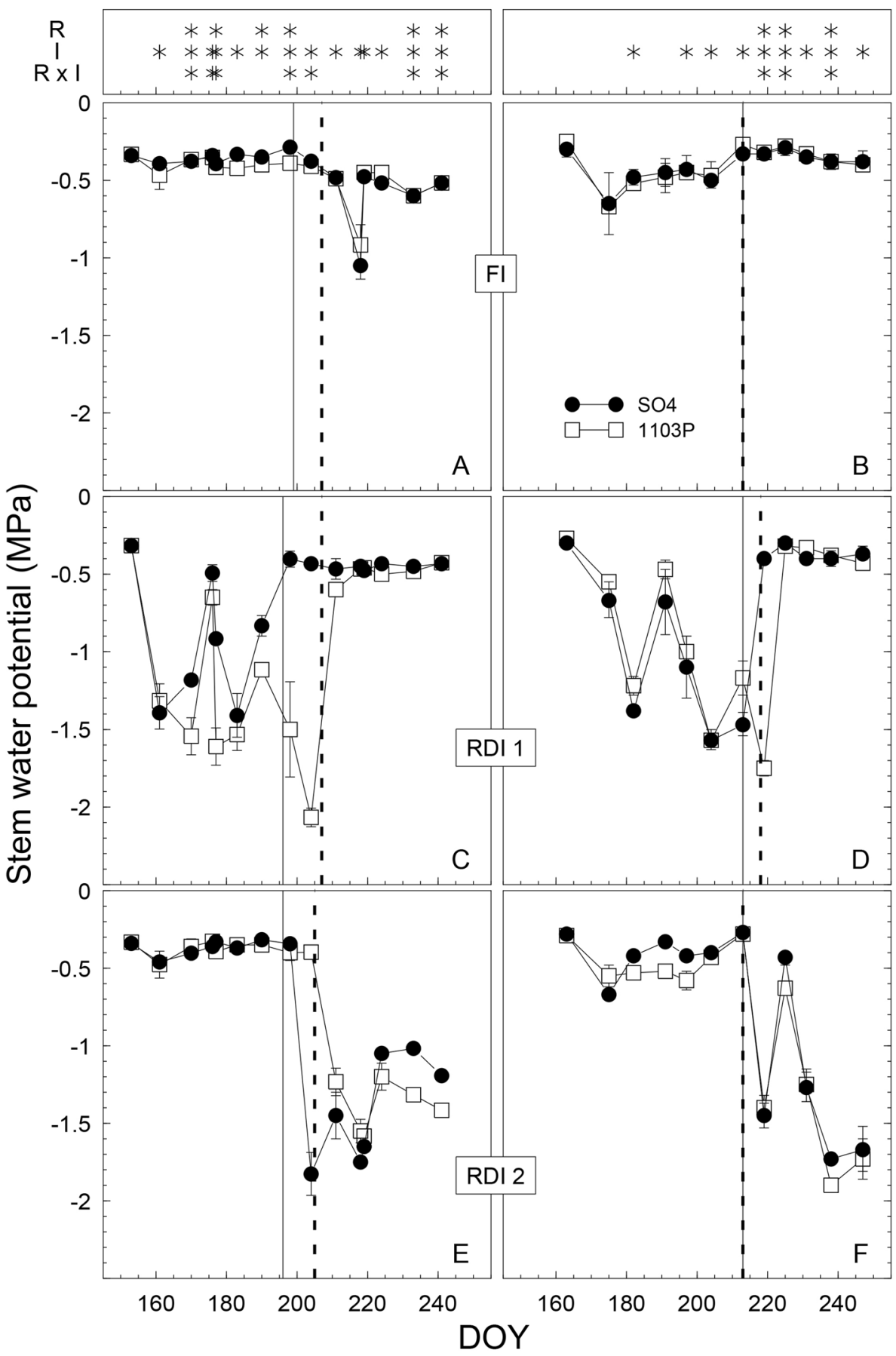

both rootstocks, differences in daily WSI between 1103P and SO4 remained significant (data not shown). In 2018, significant differences in WSI between rootstocks were measured after veraison $(-0.84$ and $-0.67 \mathrm{MPa} \cdot$ day for $\mathrm{SO} 4$ and $1103 \mathrm{P}$, respectively).

\section{Vegetative growth}

In 2018, the increment in TD readily responded to the irrigation regime. The effect was marked early during the growing season, but not so evident when water was restricted in the post-veraison period. It should be noted that increments of trunk diameter of FI vines almost stopped after veraison (Fig. 2A). Values of TD increment were smaller for the SO4 than the 1103P rootstock for both FI and RDI 2 treatment, but not for RDI 1 (Fig. 2A, C, E). Trunk shrinkage was more pronounced in RDI 1 vines grafted on 1103P than in SO4 (Fig. 2C).

Differences in canopy volume between rootstocks were significant at the beginning of the differentiation of the 
Fig. 2 Seasonal course of trunk diameter increment in 2018 (A,

C, E) and canopy volume measured in $2019(\mathbf{B}, \mathbf{D}, \mathbf{F})$ in grapevines (cv. Sangiovese) grafted on $1103 \mathrm{P}$ or $\mathrm{SO} 4$ rootstocks and subjected to different irrigation regimes (FI, full irrigation; RDI 1, water deficit applied from fruit set to veraison; and RDI 2, water deficit from veraison to harvest). Values are means \pm standard error of five vines per treatment. Asterisks in top insert indicate significant effects for rootstock (R), irrigation (I), and $\mathrm{R} \times \mathrm{I}$ interaction, calculated after ANOVA $(p<0.05)$ for a split-plot design (R main factor, I sub-factor). Solid (SO4) and dotted (1103P) vertical lines indicate the date of veraison within each irrigation treatment. Arrows indicate the beginning of the water stress imposition on RDI 1 vines.

Trunk diameter increments were normalized against values at the beginning of the experiment (trunk diameter $=0$ )

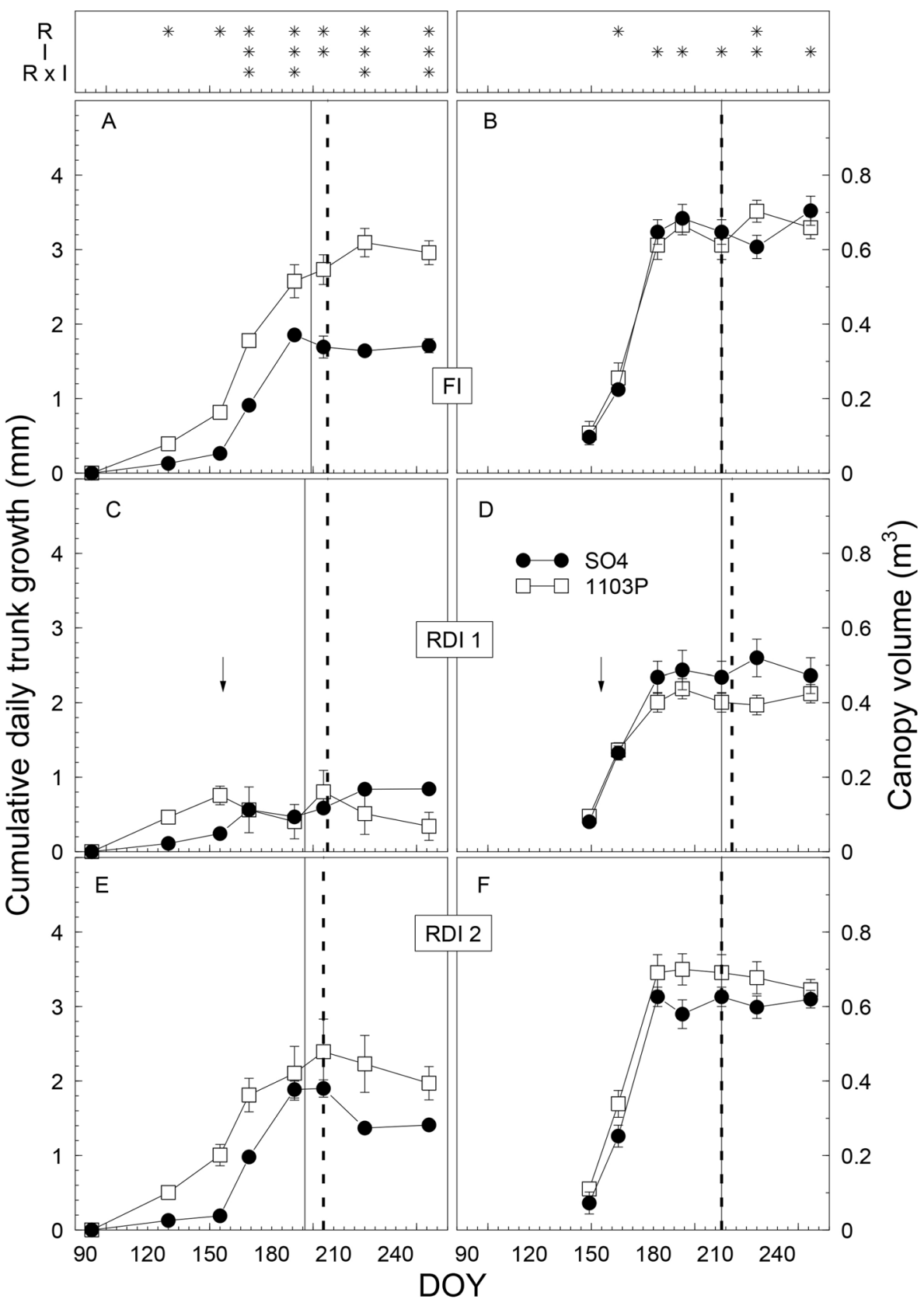

irrigation regimes in 2018. Vines grafted on 1103P had bigger canopies $\left(0.34 \pm 0.03 \mathrm{~m}^{3}\right)$ than those grafted on $\mathrm{SO} 4$ $\left(0.23 \pm 0.05 \mathrm{~m}^{3}\right)$ (values are means \pm standard deviation). In 2019 , canopy volume readily responded to water stress in the FS-V period, but not later (Fig. 2D). Significant differences between irrigation treatments were evident starting about 20 days after the beginning of differentiation (DOY 184) and lasted until harvest (Fig. 2B, D, F). At veraison, the canopy volume of fully irrigated vines was $153-180 \%$ (for $1103 \mathrm{P}$ and SO4, respectively) and $89-103 \%$ than those of RDI 1 and RDI 2 vines, respectively.

The rootstock significantly affected internode length and pruning weight only in 2018. Pruned wood per vine was significantly affected by irrigation in both years. Similar values for FI and RDI 2, but significantly lower values for RDI 1 (for SO4-grafted vines only in 2019) (Supplementary Table 1). RDI 1 vines produced about $-37 \%$ and $-27 \%$ pruned canes with respect to FI and RDI 2 vines, respectively (average of 2 years).

\section{Yield, berry weight, and juice composition}

There was no significant effect of the rootstock on yield, yield-to-pruning weight ratio, and berry characteristics with the exception of berry FW in 2018 and pH in 2019 (Table 3). On the other hand, the effect of irrigation was 
Table 3 Yield, berry fresh and dry weight, SSC, pH, TA of juice, and yield-to-pruning weight ratio measured in 2018 and 2019 in grapevines (cv. Sangiovese) grafted on 1103P or SO4 rootstocks and sub- jected to different irrigation regimes (FI, full irrigation; RDI 1, water deficit applied from fruit set to veraison; and RDI 2, water deficit from veraison to harvest)

\begin{tabular}{|c|c|c|c|c|c|c|c|c|c|}
\hline Year & Rootstock & Irrigation & $\begin{array}{l}\text { Yield } \\
\text { (g per vine) }\end{array}$ & $\begin{array}{l}\text { Berry FW } \\
(\mathrm{g})\end{array}$ & Berry DW (g) & SSC $\left({ }^{\circ}\right.$ Brix $)$ & $\mathrm{pH}$ & $\begin{array}{l}\text { TA } \\
\left(\mathrm{g} \mathrm{L}^{-1} \text { tartrate }\right)\end{array}$ & $\begin{array}{l}\text { Yield-to- } \\
\text { pruning weight } \\
\text { ratio }\end{array}$ \\
\hline \multirow[t]{6}{*}{2018} & \multirow[t]{3}{*}{$1103 \mathrm{P}$} & FI & $1752 \pm 172$ & $2.55 \pm 0.15$ & $0.56 \pm 0.03$ & $21.0 \pm 0.13$ & $3.68 \pm 0.02$ & $6.02 \pm 0.03$ & $2.3 \pm 0.3$ \\
\hline & & RDI 1 & $1658 \pm 366$ & $1.65 \pm 0.13$ & $0.36 \pm 0.05$ & $20.9 \pm 0.49$ & $3.86 \pm 0.03$ & $4.53 \pm 0.15$ & $3.1 \pm 0.8$ \\
\hline & & RDI 2 & $1886 \pm 149$ & $2.62 \pm 0.03$ & $0.57 \pm 0.01$ & $21.9 \pm 0.10$ & $3.66 \pm 0.01$ & $7.17 \pm 0.02$ & $2.8 \pm 0.3$ \\
\hline & \multirow[t]{3}{*}{$\mathrm{SO} 4$} & FI & $1228 \pm 97$ & $1.99 \pm 0.02$ & $0.40 \pm 0.01$ & $21.1 \pm 0.54$ & $3.75 \pm 0.03$ & $5.84 \pm 0.06$ & $1.9 \pm 0.2$ \\
\hline & & RDI 1 & $1269 \pm 213$ & $1.90 \pm 0.05$ & $0.41 \pm 0.02$ & $20.4 \pm 0.20$ & $3.81 \pm 0.03$ & $5.43 \pm 0.07$ & $2.3 \pm 0.3$ \\
\hline & & RDI 2 & $1278 \pm 312$ & $2.22 \pm 0.05$ & $0.49 \pm 0.01$ & $22.7 \pm 0.16$ & $3.73 \pm 0.01$ & $6.73 \pm 0.04$ & $2.6 \pm 0.6$ \\
\hline \multirow[t]{6}{*}{2019} & \multirow[t]{3}{*}{$1103 \mathrm{P}$} & FI & $2296 \pm 328$ & $2.41 \pm 0.07$ & $0.46 \pm 0.13$ & $19.5 \pm 0.53$ & $3.53 \pm 0.03$ & $6.20 \pm 0.09$ & $3.4 \pm 0.7$ \\
\hline & & RDI 1 & $1746 \pm 163$ & $1.72 \pm 0.06$ & $0.44 \pm 0.07$ & $22.2 \pm 0.18$ & $3.67 \pm 0.43$ & $4.91 \pm 0.04$ & $4.4 \pm 0.6$ \\
\hline & & RDI 2 & $2432 \pm 173$ & $2.04 \pm 0.04$ & $0.51 \pm 0.05$ & $22.0 \pm 0.07$ & $3.55 \pm 0.02$ & $5.88 \pm 0.05$ & $3.6 \pm 0.5$ \\
\hline & \multirow[t]{3}{*}{$\mathrm{SO} 4$} & FI & $1652 \pm 174$ & $2.16 \pm 0.04$ & $0.46 \pm 0.07$ & $20.0 \pm 0.66$ & $3.55 \pm 0.03$ & $5.88 \pm 0.10$ & $2.0 \pm 0.3$ \\
\hline & & RDI 1 & $1885 \pm 165$ & $1.72 \pm 0.01$ & $0.34 \pm 0.10$ & $21.0 \pm 0.72$ & $3.77 \pm 0.02$ & $4.58 \pm 0.12$ & $5.0 \pm 0.7$ \\
\hline & & RDI 2 & $2068 \pm 75$ & $1.95 \pm 0.01$ & $0.47 \pm 0.10$ & $22.4 \pm 0.21$ & $3.66 \pm 0.05$ & $6.08 \pm 0.11$ & $3.0 \pm 0.2$ \\
\hline \multirow[t]{3}{*}{2018} & \multicolumn{2}{|l|}{$\mathrm{R}$} & n.s & 0.0140 & n.s & n.s & n.s & n.s & n.s \\
\hline & \multicolumn{2}{|l|}{ I } & n.s & 0.0006 & 0.0033 & 0.010 & 0.0001 & $<0.0001$ & n.s \\
\hline & \multicolumn{2}{|l|}{$\mathrm{R} \times \mathrm{I}$} & n.s & 0.0096 & 0.0280 & n.s & n.s & $<0.0001$ & n.s \\
\hline \multirow[t]{3}{*}{2019} & \multicolumn{2}{|l|}{$\mathrm{R}$} & n.s & n.s & n.s & n.s & 0.0381 & n.s & n.s \\
\hline & \multicolumn{2}{|l|}{ I } & n.s & 0.0003 & 0.0008 & 0.0038 & 0.0002 & $<0.0001$ & 0.0062 \\
\hline & \multicolumn{2}{|l|}{$\mathrm{R} \times \mathrm{I}$} & n.s & 0.0139 & n.s & 0.0420 & n.s & 0.0136 & n.s \\
\hline
\end{tabular}

Values are means \pm standard error of three (berry FW and berry DW) or five (yield, ${ }^{\circ} \mathrm{Brix}, \mathrm{pH}$, TA, and yield-to-pruning weight ratio) vines per treatment. Significant differences for rootstock (R), irrigation (I), and $\mathrm{R} \times \mathrm{I}$ were calculated using R and I as main- and sub-factor, respectively $F W$ fresh weight, $D W$ dry weight, $S S C$ soluble solid content, $T A$ titratable acidity, n.s. not significant

always significant except for yield (both years) and yieldto-pruning weight ratio in 2018 . There was a significant interaction between $\mathrm{R}$ and I for berry $\mathrm{FW}, \mathrm{DW}$, juice TA in 2018, and for berry FW and TA in 2019 (Table 3). Yields were comprised between 1228 and $1886 \mathrm{~g} \mathrm{vine}^{-1}$ and 1652 and $2432 \mathrm{~g} \mathrm{vine}^{-1}$ in 2018 and 2019, respectively (Table 3). Berry FW was lower for RDI 1 than for FI or RDI 2 vines grafted on 1103P in 2018 (only lower than RDI 2 for SO4). In 2019, berry FW was again lower for RDI 1 than for FI or RDI 2 vines grafted on 1103P, and FW of FI was greater than RDI 2 (Table 3). Berry FW of FI vines grafted on SO4 was higher than that of RDI 1 in both years, whereas berry DW only in 2019.

Grapes were harvested when SSC reached $22 \pm 0.5^{\circ}$ Brix, but some treatments (e.g., FI in both years, RDI 1 in SO4 in both years, and RDI 1 in 1103P in 2018) never reached this threshold, because berry sugar accumulation stopped prematurely (data not shown). The highest and lowest values of $\mathrm{pH}$ and $\mathrm{TA}$, respectively, were measured in juice from berries of RDI 1 vines in 2018 and 2019 (Table 3). Yield-to-pruned wood was similar across irrigation regimes for both rootstocks in 2018, but higher for RDI 1 than other treatments in 2019 (Table 3).
In both years, the highest anthocyanins concentrations were measured in RDI 1 berries regardless of the rootstock used. Berries sampled from vines grafted on 1103P subjected to early water deficit had anthocyanins concentration higher (175 and 132\%) than those of FI and RDI 2 vines ones, respectively (average of 2 years). Similar results were observed in SO4-grafted vines in 2019, whereas higher differences between RDI 1 and the other irrigation treatments were measured in 2018 (Table 4).

The relationship between anthocyanins concentration at harvest and water stress experienced by FI or RDI 1 vines before veraison showed that berry anthocyanins increased as the daily WSI reached values of about $-0.8 \mathrm{MPa}$ and declined with further stress when data from both years were plotted together (Fig. 3). The relationship was similar for both rootstocks, even though values of WSI lower than that threshold were measured only on vines grafted on $1103 \mathrm{P}$ (Fig. 3A). The water stress applied after veraison resulted in a less clear relationship between anthocyanins concentration and daily WSI than that observed in RDI 1 vines (Fig. 3B).

Skin flavonoids were significantly affected by rootstock only in 2018 when Sangiovese-1103P berries showed higher values $(+22 \%)$ than those measured for Sangiovese-SO4 


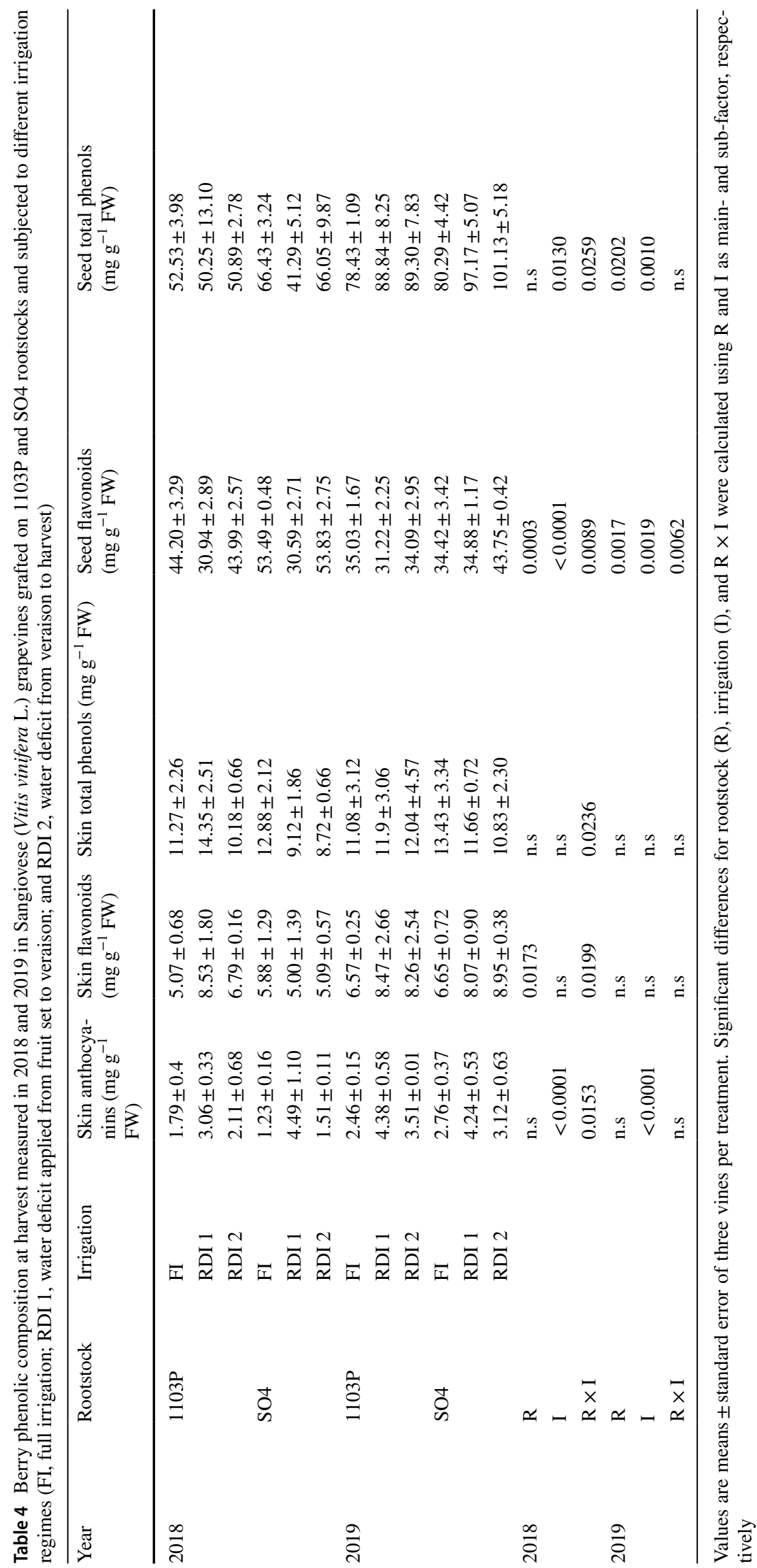


Fig. 3 The relationships between the daily water stress integral (WSI) and anthocyaof grapevines (cv. Sangiovese) grafted on $1103 \mathrm{P}$ or $\mathrm{SO} 4$ rootstocks and subjected to different irrigation regimes (FI, full irrigation; RDI 1, water deficit applied from fruit set to veraison; RDI 2, water deficit from veraison to harvest). The two experimental years are plotted together and each symbol represents one vine. The WSI was calculated for the period between fruit set and veraison (A) and between veraison and nins concentrations at harvest harvest (B)
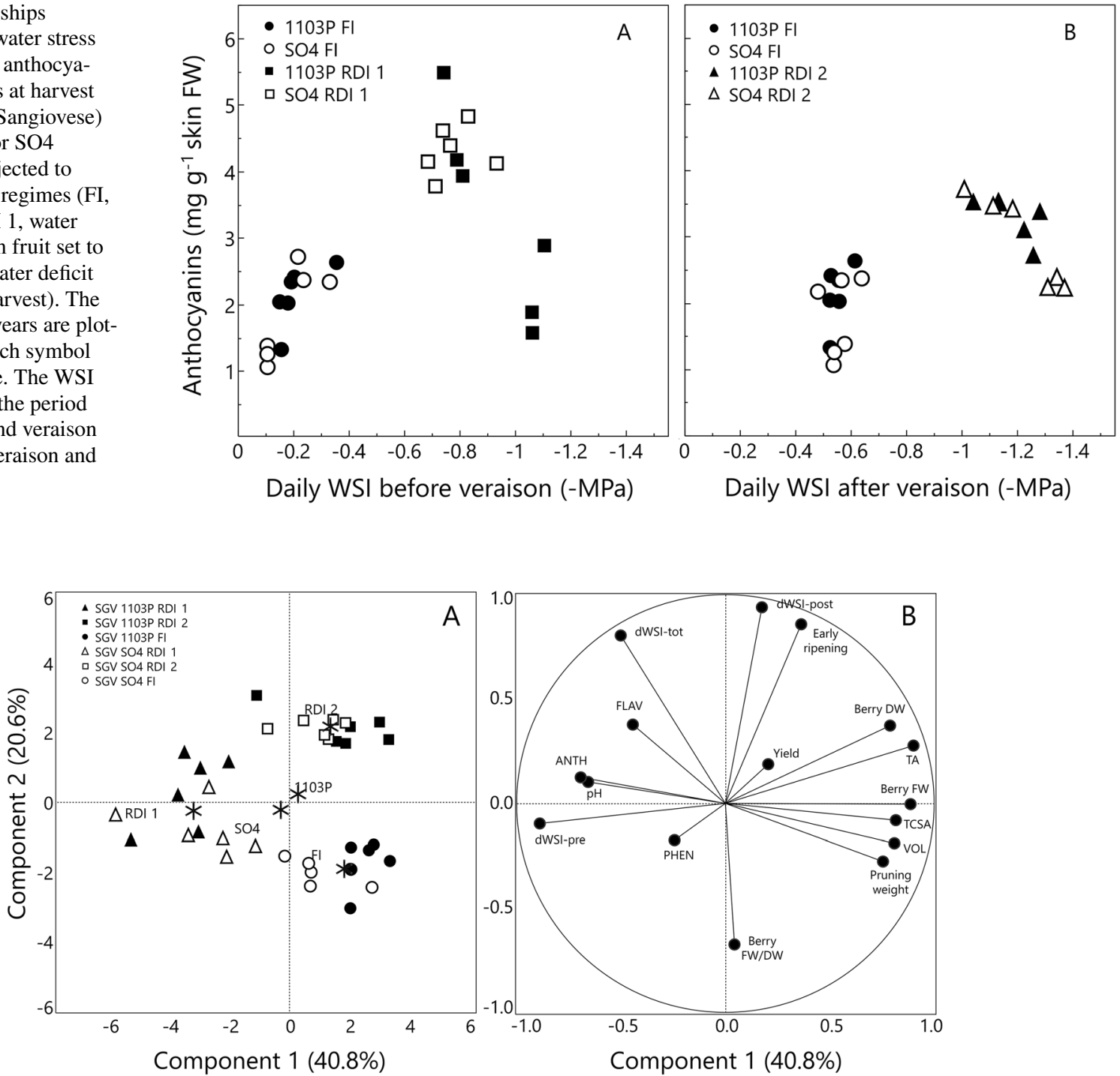

Fig. 4 Score plot (A) and loading plot (B) of Principle Component Analysis (PCA) of grapevines (cv. Sangiovese) grafted on 1103P or $\mathrm{SO} 4$ rootstocks and subjected to different irrigation regimes (FI, full irrigation; RDI 1, water deficit applied from fruit set to veraison; and RDI 2, water deficit from veraison to harvest). The analysis was performed using the following 16 variables: daily water stress integral before veraison (dWSI-pre), daily water stress integral after veraison (dWSI-post), daily water stress integral of entire season (dWSI-tot),

ones (average across irrigation treatments). Skin total phenols were also higher $(+14 \%)$ for Sangiovese-1103P in 2018, but differences were not significant. Irrigation, rootstock, and their interaction had a significant effect on seed flavonoids in both growing seasons; in 2018, seed flavonoids of RDI 1 were definitely lower than in the other irrigation regimes, whereas in 2019 , they showed the same values as FI vines (Table 4). In 2019, higher values of total phenols were measured in seeds sampled from vines grafted on $\mathrm{SO} 4$. fruits production per vine (yield), pruning weight per vine (pruning weight), trunk cross sectional area (TCSA), canopy volume (Can VOL), stage of ripening (early ripening), total anthocyanins concentration (ANTH), total skin flavonoids concentration (FLAV), total skin phenols concentration (Tot PHEN), berry juice $\mathrm{pH}(\mathrm{pH})$, berry juice titratable acidity (TA), berry fresh weight (Berry FW), berry dry weight (Berry DW), and berry fresh weight-to-dry weight ratio (berry FW/DW)

The two principal components described $61.4 \%$ of the total variation (Fig. 4). In particular, PC1 and PC2 had eigenvalues of 6.53 and 3.30, respectively, and described $40.8 \%$ and $20.6 \%$ of the total variance. Both PC1 and PC2 mainly described the effect of the irrigation treatments on vegetative, productive, and quality-related parameters, whereas the effect of the rootstock was not evident (Fig. 4A). The score plot and loading plot showed that RDI 1 vines were mainly characterized by high values of anthocyanins and skin flavonoids concentrations and high juice $\mathrm{pH}$. On the 
other hand, RDI 2 vines were characterized by early berry ripening, high juice TA, and berry dry weight. High vigour parameters (TCSA, canopy volume, and pruning weight) characterized the FI treatments (Fig. 4B).

\section{Discussion and conclusions}

Weather conditions were quite different in the two consecutive growing seasons of our study. April and May were cooler in 2019 than in 2018 and, consequently, flowering was delayed by about 2 weeks with respect to the previous year. In 2019, vegetative growth was initially slower than in 2018 , but later in 2019 , the growing season was more favorable for vegetative activity. Similar conditions were widespread across the main viticultural areas of Tuscany where vineyards were harvested about 20 days later than in 2018 . As a result, the timing and duration of RDI regimes had to be adjusted to the onset of phenological stages, which caused some changes in the experimental protocol. For instance, the volume of irrigation water supplied at the end of the experiment was greater for RDI 1 than RDI 2 in 2018, but the opposite was true in 2019 (although not to same extent). In any case, the level of maximum deficit we imposed was more severe $\left(\Psi_{\text {stem }}\right.$ minima below - 2.0 MPa were reached in both years) and/or maintained for longer periods than in the previous studies (Alsina et al. 2011; Basile et al. 2011; Girona et al. 2009; Merli et al. 2015; Palliotti et al. 2014). Despite the lack of weather uniformity in the two growing seasons, which might have been responsible for the different vegetative activity of similar treatments between 2018 and 2019 , there are consistent results from our work.

First, water deficit imposed at the beginning of berry development (fruit set until veraison corresponding to RDI 1) had a greater inhibitory effect on trunk diameter, canopy volume, and weight of pruned wood than that applied from veraison to harvest (RDI 2), in agreement with findings from previous works (Intrigliolo et al. 2008; Munitz et al. 2017; Palliotti et al. 2014; Romero et al. 2010). In fact, the main period for vegetative growth in grapevines occurs between flowering and bunch closure, that is before veraison. On the contrary, when water deficit developed after veraison the subsequent canopy expansion only slightly contributed to final canopy volume. Canopy growth and pruned wood of RDI 1 only partially recovered to the corresponding values of RDI 2 at harvest and never reached those of FI vines (Fig. 3, Supplementary Table 1).

Second, the role of the rootstock was quite complex. Vines grafted on 1103P showed a higher sensitivity of trunk growth to fluctuations in soil water availability than SO4. Under well-watered conditions, the TD increment of 1103P was higher than that measured in $\mathrm{SO} 4$, but water restrictions determined a more evident trunk shrinkage for 1103P. It is likely that under non-limiting water conditions, the more vigorous rootstock 1103P induced a higher growth rate of trunk than that of vines on $\mathrm{SO} 4$, similarly to what probably occurs under field conditions when soil moisture is adequate. Larger differences in leaf area index and vegetative growth due to soil water availability were reported for field-grown, mature vines of cv. Cabernet Sauvignon grafted on 1103P than on SO4 (Koundouras et al. 2008). On the other hand, the root system of mature vines could not expand to explore new soil as it was constrained by the container and the onset and progression of stress was faster. In field-grown grapevines, wide and deep root systems allow to sustain large canopies, while large canopies can develop in containers only if water is abundantly supplied artificially. Therefore, the genotype effect on root distribution and density is lost in container-grown vines. As a result, the high leaf area-toroot ratio can lead to partial dehydration of woody tissues and leaf shedding in response to water scarcity, mechanisms whereby the plant tries to adjust its water consumption to the reduced supply when water stress develops. Previous studies indicated that internal water redistribution might play an important role in drought resistance of woody perennials (Bauerle et al. 2008; Smart et al. 2005). It has also been shown that the rootstock influences water uptake and transport to the scion in four grapevine cultivars (Tramontini et al. 2013). The root hydraulic conductance of the more vigorous and drought-tolerant 1103P rootstock was higher than that of the weaker and drought sensitive 101-14 MGt, but did not depend on xylem anatomy (Alsina et al. 2011). Under field conditions, the key feature to explain the different sensitivity to drought of mature vines (cv. Merlot) grafted on 1103P and 101-14 MGt was the enhanced ability of 1103P to produce fine, absorbing roots in deep layers of the soil when water deficit developed (Alsina et al. 2011). Since we used potted vines with confined root systems, we can only indirectly infer that the lack of the rootstock effect on water relations and vegetative growth was probably caused by restrictions to root proliferation and colonization of new soil volumes. In fact, the seasonal pattern of canopy volume in 2019 did not show any differences between 1103P and SO4 rootstocks under water-deficit conditions both before and after veraison. Koundouras et al. (2008) observed a significantly higher vegetative growth in field-grown 1103P-grafted Cabernet vines compared to $\mathrm{SO} 4$ and attributed this result to the larger root system of 1103P. Similar findings on the effect of root system on canopy growth were also reported in other studies (De Herralde et al. 2006; Winkel and Rambal 1993).

Although conclusive results on the relationship between vigour and drought resistance can be obtained only when rootstocks are compared under field conditions, physiological mechanisms can be investigated using plants grown in containers. Tramontini et al. (2013) reported that the 
vigorous rootstock 140 Ruggeri supplied larger amounts of water to the scion thanks to higher root hydraulic conductance than SO4. Hence, 140 Ruggeri rootstock depleted soil water faster than SO4. In 2018, the effect of water restriction before veraison was more pronounced (more negative $\Psi_{\text {stem }}$ values) in grapevines grafted on $1103 \mathrm{P}$, which had larger (148\%) canopies than in SO4 ones at the beginning of the irrigation differentiation. The higher canopy size of 1103P-grafted vines probably led to a faster water consumption and, in general, to a higher water demand with respect to SO4 vines. Thus, vine water status was not only driven by the irrigation regime, but also by differences in canopy size between rootstocks. Moreover, considering that the drought tolerance of $1103 \mathrm{P}$ is conveyed to the scion through deep root proliferation under low water availability in the soil (Alsina et al. 2011), it is evident that in potted vines, the discrepancy between leaf area and root biomass could induce an apparent contrasting behavior of 1103P to water shortage. In support of this hypothesis, in 2019, $\Psi_{\text {stem }}$ values were similar in grapevine grafted on both rootstocks, probably due to the similar canopy size at the beginning of the irrigation differentiation.

Yield was unaffected by either irrigation or rootstock in both years. This is not surprising as the number of buds per vine left after winter pruning was similar for all treatments and cv. Sangiovese is characterized by high fertility of basal buds. Yield was comparable with values reported for potted vines of Sangiovese (Merli et al. 2015; Palliotti et al. 2014). Irrigation had a marked effect on berry FW and juice technological parameters. Must composition was unaffected by the rootstock, even though climatic conditions were different in the 2 years of the investigation. Nuzzo and Matthews (2006) also reported that fruit ripening (cv. Cabernet Sauvignon) was quite insensitive to rootstock, whereas a few and inconsistent effects on berry and juice composition of cv. Malbec grafted on different rootstocks were shown by Di Filippo and Vila (2011). An early RDI produced lighter berries, confirming that the early phase of berry growth, when cell division processes are active (Hardie and Considine 1976; McCarthy 1997), is highly sensitive to water deficit (Basile et al. 2011; Merli et al. 2016; Munitz et al. 2017; Palai et al. 2021; Palliotti et al. 2014). If water deficit is severe enough, fruit growth cannot recover to restore berry size to non-stressed values even if stress is fully relieved during the post-veraison period (Merli et al. 2015; Palliotti et al. 2014). The results also showed that post-veraison water deficit seldom results in limitations in berry size at harvest compared with well-watered vines, similarly to previous studies on cvs. Sangiovese and Merlot (Munitz et al. 2017; Palliotti et al. 2014).

Irrigation significantly affected SSC, $\mathrm{pH}$, and TA of the berry juice. Post-veraison RDI determined higher $\mathrm{TA}$ and lower $\mathrm{pH}$ of berry juice than RDI at pre-veraison
(Table 4). Since the lowest values of TA were measured in RDI 1 vines, it is likely that the high levels of water stress applied between fruit set and veraison negatively affected the organic acids biosynthesis (Hochberg et al. 2013; Gerós et al. 2012). In fact, TA at veraison was significantly lower in RDI $1\left(14.0 \pm 5.2\right.$ and $15.9 \pm 0.9 \mathrm{~g} \mathrm{~L}^{-1}$ of tartrate in 2018 and 2019, respectively) than in FI (22.2 \pm 2.1 and $20.5 \pm 0.9)$ and RDI 2 vines $(22.2 \pm 2.1$ and $20.3 \pm 1.0)$. Similar results were observed in another experiment carried out on potted vines of cv. Tempranillo where TA was inversely correlated with leaf water potential measured from fruit set to veraison, whereas water status during stages I and III (from anthesis to full fruit set and from $60 \%$ of veraison to harvest, respectively) did not affect TA (Girona et al. 2009). Since we established the harvest date based on reaching a threshold of approximately $22^{\circ}$ Brix SSC, we cannot attribute differences in SSC values of juice reported in Table 4 to irrigation regimes. Nevertheless, even though RDI 2 vines were harvested 14-24 days earlier than FI and RDI1 ones, SSC values were higher than other treatments in 2018 and similar in 2019. Previous studies reported that SSC were positively affected by post-veraison water stress through a dehydration-concentration effect on berry solutes (Basile et al. 2011; Intrigliolo et al. 2016). Pastenes et al. (2014) observed that post-veraison water stress induced a faster sugar accumulation increasing the abundance of transcripts of hexose and sucrose transport. Furthermore, Deluc et al. (2009) suggested that ABA was a activator for the uptake of hexoses in berries of Cabernet vines affected by late water deficit. As for FI vines that had stopped sugar accumulation before $22^{\circ}$ Brix, they had to be harvested even if the established threshold had not been reached to avoid the occurrence of grey mold. The behavior of FI vines could be related to possible modifications in sugar partitioning between leaves and fruits. After veraison, shoot-to-berry competition for carbohydrates can inhibit shoot growth, but in FI vines, the absence of water limitation leads to a vigorous canopy growth which, in turn, reduced carbohydrate partitioning to berries (Bravdo et al. 1985; Dokoozlian and Kliewer 1996).

Early water deficit imposed between fruit set and veraison determined significantly higher concentrations of berry anthocyanins than those measured in FI vines, whereas RDI 2 berries had intermediate values. Similar results were obtained in Cabernet Sauvignon-140 Ruggeri and Tempranillo-161-49 cultivar/rootstock combinations (Castellarin et al. 2007; Intrigliolo and Castel 2010). The expression analysis of genes involved in the synthesis of anthocyanins in grape berries showed that water restrictions during the pre-veraison period promoted the synthesis of phenolic pigments in berries (Castellarin et al. 2007). Not significant differences were found in total anthocyanins between the two rootstocks, confirming the previous findings (Koundouras et al. 2009). On the contrary, Gutierrez-Gamboa et al. 
(2019) measured the highest anthocyanins and tannins content in berries of SO4-grafted Merlot vines out of nine rootstock-scion combinations. We also showed that anthocyanins concentration reached a peak when pre-veraison daily WSI was about $-0.9 \mathrm{MPa}$ and decreased when stress was less or more severe than that value in both rootstocks (Fig. 4A). Girona et al. (2009) also reported the negative effect of severe water deficit between fruit set and veraison on final concentration. Thus, it can be hypothesized that preveraison water deficit can be a useful practice to optimize berry anthocyanins concentrations in the vineyard. There was a similar relationship between anthocyanins and water stress applied post-veraison (Fig. 4B), but the anthocyanins concentrations were lower than in RDI 1 berries, probably because the anthocyanins biosynthetic pathway becomes less sensitive to regulation after veraison (Castellarin et al. 2007). In addition, the increase in water loss and/or a greater thickening of the epicarp that occur post-veraison may partially contribute to the post-veraison effect (Roby et al. 2004).

The inconsistent effect of rootstock and irrigation on skin flavonoids, which included anthocyanins, proanthocyanidins, flavan-3-ols and flavanols, between years could be due to the different impact of environmental factors on the biosynthesis of the different flavonoids classes (Downey et al. 2006). A positive effect of an early water deficit on flavonols accumulation was found in Shiraz grapevines grafted on Fercal (Ojeda et al. 2002). Conversely, Ollè et al. (2011) did not observe any effect of water stress applied before veraison on proanthocyanidins of berries sampled from the same scion-rootstock combination when water stress was applied before veraison. The lowest values of seeds flavonoids we measured in RDI 1 berries confirmed that the pre-veraison is the critical period for the biosynthesis of seed flavonoids (Kennedy et al. 2000).

From the practical standpoint, an RDI 1 strategy may be beneficial in cases of high vigour (e.g., high soil fertility and vigorous rootstock-scion combination) as a management practice to reduce vegetative growth and canopy expansion of Sangiovese vines, whereas RDI 2 only slightly affected vegetative growth. Both RDI strategies were beneficial for Sangiovese grapevines in terms of berry quality even if some limitations emerged for each of them. The RDI 1 regime determined the highest values of anthocyanins and flavonoids concentrations, but it could be deleterious for sugar accumulation and TA if it excessively weakens canopy development, which becomes insufficient to feed and mature bunches properly. Post-veraison water deficit allows to sustain rapid sugar accumulation and maintain TA and anthocyanins. Under well-irrigated conditions, the high vigour induced by $1103 \mathrm{P}$ could be disadvantageous, because it implies qualitative side effects as well as high water needs. This problem may also arise with an RDI 2 strategy when
Sangiovese vines are grafted on vigorous rootstocks grown under favorable environmental and soil conditions for vegetative activity, because severe water stress may develop fast after veraison when deficit is applied.

Supplementary Information The online version contains supplementary material available at https://doi.org/10.1007/s00271-022-00773-3.

Acknowledgements This research was supported by NETAFIM Italy, project "Identification of optimal irrigation strategies for grapevine, olive and hazelnut" and Fondazione Bertarelli and Colle Massari s.p.a. We thank Rolando Calabrò, Massimo Frassi, and Marcello Di Giacomo for technical assistance.

\section{Declarations}

Conflict of interest On behalf of all authors, the corresponding author states that there is no conflict of interest.

Open Access This article is licensed under a Creative Commons Attribution 4.0 International License, which permits use, sharing, adaptation, distribution and reproduction in any medium or format, as long as you give appropriate credit to the original author(s) and the source, provide a link to the Creative Commons licence, and indicate if changes were made. The images or other third party material in this article are included in the article's Creative Commons licence, unless indicated otherwise in a credit line to the material. If material is not included in the article's Creative Commons licence and your intended use is not permitted by statutory regulation or exceeds the permitted use, you will need to obtain permission directly from the copyright holder. To view a copy of this licence, visit http://creativecommons.org/licenses/by/4.0/.

\section{References}

Alsina MM, Smart DR, Bauerle T, De Herralde F, Biel C, Stockert C, Negron C, Save R (2011) Seasonal changes of whole root system conductance by a drought-tolerant grape root system. J Exp Bot 62:99-109

Basile B, Marsal J, Mata M, Vallverdú X, Bellvert J, Girona J (2011) Phenological sensitivity of cabernet sauvignon to water stress: vine physiology and berry composition. Am J Enol Vitic 62:453-461

Bauerle TL, Richards JH, Smart DR, Eissenstat DM (2008) Importance of internal hydraulic redistribution for prolonging lifespan of roots in dry soil. Plant Cell Environ 31:177-186

Bravdo B, Hepner Y, Loinger C, Tabacman H (1985) Effect of irrigation and crop level on growth, yield and wine quality of cabernet sauvignon. Am J Enol Vitic 36:132-139

Carbonneau A (1985) The early selection of grapevine rootstocks for resistance to drought conditions. Am J Enol Vitic 36:195-198

Caruso G, Tozzini L, Rallo G, Primicerio J, Moriondo M, Palai G, Gucci R (2017) Estimating biophysical and geometrical parameters of grapevine canopies ('sangiovese') by an unmanned aerial vehicle (UAV) and VIS-NIR cameras. Vitis 56(2):63-70

Castellarin SD, Pfeiffer A, Sivilotti P, Degan M, Peterlunger E, Di Gaspero G (2007) Transcriptional regulation of anthocyanin biosynthesis in ripening fruits of grapevine under seasonal water deficit. Plant Cell Environ 30:1381-1399 
Chaves MM, Oliveira MM (2004) Mechanisms underlying plant resilience to water deficits: prospects for water-saving agriculture. J Exp Bot 55:2365-2384

Chaves MM, Zarrouk O, Francisco R, Costa JM, Santos T, Regalado AP, Rodrigues ML, Lopes CM (2010) Grapevine under deficit irrigation: hints from physiological and molecular data. Ann Bot 105:661-676

Coombe BG (1995) Adoption of a system for identifying grapevine growth stages. Aust J Grape Wine Res 1:104-110

Coombe BG, McCarthy MG (2000) Dynamics of grape berry growth and physiology of ripening. Aust J Grape Wine Res 6:131-135

Cuneo IF, Barrios-Masias F, Knipfer T, Urestky J, Reyes C, Lenain P, Brodersen CR, Walker MA, McElrone AJ (2021) Differences in grapevine rootstock sensitivity and recovery from drought are linked to fine root cortical lacunae and root tip function. New Phytol 229:272-283

De Herralde F, Alsina MM, Aranda X, Savé R, Biel C (2006) Effects of rootstock and irrigation regime on hydraulic architecture of Vitis vinifera L cv Tempranillo. Int J Vine Wine Sci 40:133-213

De Souza CR, Maroco JP, dos Santos TP, Rodrigues ML, Lopes CM, Pereira JS, Chaves MM (2003) Partial rootzone drying: regulation of stomatal aperture and carbon assimilation in field-grown grapevines (Vitis vinifera cv Moscatel). Funct Plant Biol 30:653-662

Deluc LG, Quilici DR, Decendit A, Grimplet J, Wheatley MD, Schlauch KA, Mèrillon JM, Cushman JC, Cramer GR (2009) Water deficit alters differentially metabolic pathways affecting important flavor and quality traits in grape berries of cabernet sauvignon and chardonnay. BMC Genom 10:212. https://doi.org/ 10.1186/1471-2164-10-212

Di Filippo M, Vila H (2011) Influence of different rootstocks on the vegetative and reproductive performance of Vitis vinifera $\mathrm{L}$ Malbec under irrigated conditions. J Int Sci Vigne Vin 45:75-84

Di Stefano R, Cravero MC, Gentilini N (1989) Metodi per lo studio dei polifenoli dei vini. L'enotecnico 25:83-89

Dokoozlian NK, Kliewer WM (1996) Influence of light on grape berry growth and composition varies during fruit development. J Am Soc Hortic Sci 121:869-874

Dos Santos TP, Lopez CM, Rodrigues ML, De Souza CR, Maroco JP, Pereira JS, Silva JR, Chaves MM (2003) Partial rootzone drying: effects on growth and fruit quality of field-grown grapevines (Vitis vinifera $\mathrm{L}$ ). Funct Plant Biol 30:663-671

Downey MO, Dokoozlian NK, Krstic MP (2006) Cultural practice and environmental impacts on the flavonoid composition of grapes and wine: a review of recent research. Am J Enol Vitic 57:3

Dry PR, Loveys BR (1998) Factors influencing grapevine vigour and the potential for control with partial rootzone drying. Aust J Grape Wine Res 4:140-148

Dry PR, Loveys BR, McCarthy MG, Stoll M (2001) Strategic irrigation management in Australian vineyards. J Int Sci Vigne Vin 35:129-139

Galbignani M, Merli MC, Magnanini E, Bernizzoni F, Talaverano I, Gatti M, Tombesi S, Palliotti A, Poni S (2016) Gas exchange and water-use efficiency of cv Sangiovese grafted to rootstocks of varying water-deficit tolerance. Irrig Sci 34:105-116

Gerós H, Chaves M, Delrot S (2012) The biochemistry of the grape berry. Bentham Science, Sharjah, p 290 (ISBN 978-1-60805-360-5)

Girona J, Marsal J, Mata M, Del Campo J, Basile B (2009) Phenological sensitivity of berry growth and composition of Tempranillo grapevines (Vitis Vinifera L) to water stress. Aust J Grape Wine Res 15:268-277

Greenspan MD, Shackel KA, Matthews MA (1994) Developmental changes in the diurnal water budget of the grape berry exposed to water deficit. Plant Cell Environ 17:811-820

Gutiérrez-Gamboa G, Gómez-Plaza E, Bautista-Ortín AB, GardeCerdàn T, Moreno-Simunovic Y, Martìnez-Gil AM (2019)
Rootstock effects on grape anthocyanins, skin and seed proanthocyanidins and wine color and phenolic compounds from Vitis vinifera L. Merlot Grapevines J Sci Food Agric 99:2846-2854. https://doi.org/10.1002/jsfa.9496

Hardie WJ, Considine JA (1976) Response of grapes to water deficit stress in particular stages of development. Am J Enol Vitic 27:55-61

Hochberg U, Degu A, Toubiana D, Gendler T, Nikoloski Z, Rachmilevitch S, Fait A (2013) Metabolite profiling and network analysis reveal coordinated changes in grapevine water stress response. BMC Plant Biol 13:184

Howell GS (1987) Vitis rotstocks. In: Carlson RF, Rom RC (eds) Rootstocks for fruit crops. Wiley, New York, pp 451-472

Iacono F, Buccella A, Peterlunger E (1998) Water stress and rootstock influence on leaf gas exchange of grafted and ungrafted grapevines. Sci Hortic 75:27-39

Intrigliolo DS, Castel JR (2008) Trunk diameter variations as water stress indicator in plum and grapevine. Acta Hortic 792:363-369

Intrigliolo DS, Castel JR (2010) Response of grapevine cv. 'Tempranillo' to timing and amount of irrigation: water relations, vine growth, yield and berry and wine composition. Irrig Sci 28:113125. https://doi.org/10.1007/s00271-009-0164-1

Intrigliolo DS, Lizama V, García-Esparza MJ, Abrisqueta I, Álvarez I (2016) Effects of post-veraison irrigation regime on Cabernet sauvignon grapevines in Valencia, Spain: yield and grape composition. Agric Water Manag 170:110-119

Jackson DI, Lombard PB (1993) Environmental and management practices affecting grape composition and wine quality - a review. Am J Enol Vitic 44:409-430

Keller M, Mills LJ, Harbertson JF (2012) Rootstock effects on deficitirrigated winegrapes in a dry climate: vigor, yield formation, and fruit ripening. Am J Enol Vitic 63:29-39. https://doi.org/10.5344/ ajev.2011.11078

Kennedy JA, Troup GJ, Pilbrow JR, Hutton DR, Hewitt D, Hunter CR, Ristic R, Iland PG, Jones GP (2000) Development of seed polyphenols in berries from Vitis vinifera L. cv. Shiraz Aust J Grape Wine Res 6:244-254. https://doi.org/10.1111/j.1755-0238. 2000.tb00185.x

Koundouras S, Tsialtas JT, Zioziou E, Nikolaou N (2008) Rootstock effects on the adaptive strategies of grapevine (Vitis vinifera $\mathrm{L}$ cv Cabernet Sauvignon) under contrasting water status: leaf physiological and structural responses. Agric Ecosyst Environ 128:86-96

Koundouras S, Hatzidimitriou E, Karamolegkou M, Dimopoulou E, Kallithraka S, Tsialtas JT, Zioziou E, Nikolaou N, Kotseridis Y (2009) Irrigation and rootstock effects on the phenolic concentration and aroma potential of Vitis vinifera $\mathrm{L}$ cv cabernet sauvignon grapes. J Agric Food Chem 57:7805-7813

Lanari V, Palliotti A, Sabbatini P, Howell GS (2014) Optimizing deficit irrigation strategies to manage vine performanceand fruit composition of field-grown 'Sangiovese' (Vitis vinifera L.) grapevines. Sci Hortic 179:239-247

Lanari V, Silvestroni O, Palliotti A, Green A, Sabbatini P (2015) Plant and leaf physiological responses to water stress in potted 'vignoles' grapevine. HortScience 50(10):1492-1497

Loveys BR, Kriedemann PE (1974) Internal Control of stomatal physiology and photosynthesis I stomatal regulation and associated changes in endogenous levels of abscisic and phaseic acids. Aust J Plant Physiol 1(3):407-415

Lovisolo C, Schubert A (1998) Effects of water stress on vessel size and xylem hydraulic conductivity in Vitis vinifera L. J Exp Bot 49:693-700

Lovisolo C, Perrone I, Carra A, Ferrandino A, Flexas J, Medrano H, Schubert A (2010) Drought-induced changes in development and function of grapevine (Vitis spp) organs and in their hydraulic and 
nonhydraulic interactions at the whole-plant level: a physiological and molecular update. Funct Plant Biol 37:98-116

McCarthy MG (1997) The effect of transient water deficit on berry development on cv Shiraz (Vitis vinifera $\mathrm{L}$ ). Aust J Grape Wine Res 3:102-108

McDowell NG (2011) Mechanisms linking drought, hydraulics, carbon metabolism, and vegetation mortality. Plant Physiol 155:1051-1059

Meggio F, Prinsi B, Negri AS, Di Lorenzo G, Lucchini G, Pitacco A, Failla O, Scienza A, Espen CM (2014) Biochemical and physiological responses of two grapevine rootstock genotypes to drought and salt treatments. Austr J Grape Wine Res 20:310-323

Merli MC, Gatti M, Galbignani M, Bernizzoni F, Magnanini E, Poni S (2015) Water use efficiency in Sangiovese grapes (Vitis vinifera L) subjected to water stress before veraison: different levels of assessment lead to different conclusions. Func Plant Biol 42:198-208

Merli MC, Magnanini E, Gatti M, Pirez FJ, Pueyo IB, Intrigliolo DS, Poni S (2016) Water stress improves whole-canopy water use efficiency and berry composition of cv: sangiovese (Vitis vinifera L) grapevines grafted on the new drought-tolerant rootstock M4. Agric Water Manage 169:106-114

Munitz S, Netzer Y, Schwartz A (2017) Sustained and regulated deficit irrigation of field-grown Merlot grapevines. Aust J Grape Wine Res 23:87-94

Myers BJ (1988) Water stress integral-a link between short-term stress and long-term growth. Tree Physiol 4:315-323

Nuzzo V, Matthews MA (2006) Response of fruit growth and ripening to crop level in dry-farmed cabernet sauvignon on four rootstocks. Am J Enol Vitic 57:314-324

Ojeda H, Deloire A, Carbonneau A, Ageorges A, Romieu C (1999) Berry development of grapevines: relations between the growth of berries and their DNA content indicate cell multiplication and enlargement. Vitis 38(4):145-150

Ojeda H, Andary C, Kraeva E, Carbonneau A, Deloire A (2002) Influence of pre- and post-veraison water deficit on synthesis and concentration of skin phenolic compounds during berry growth of Vitis vinifera cv. Shiraz. Am J Enol Vitic 53:261-267

Ollé D, Guiraud JL, Souquet JM, Terrier N, Ageorges A, Cheynier V, Verries C (2011) Effect of pre- and post-veraison water deficit on proanthocyanidin and anthocyanin accumulation during Shiraz berry development: water stress and flavonoid biosynthesis. Aust J Grape Wine Res 17:90-100

Palai G, Gucci R, Caruso G, D’Onofrio C (2021) Physiological changes induced by either pre- or post-veraison deficit irrigation in "Merlot" vines grafted on two different rootstocks. Vitis 60:153-161

Palliotti A, Tombesi S, Frioni T, Famiani F, Silvestroni O, Zamboni M, Poni S (2014) Morpho-structural and physiological response of container-grown sangiovese and montepulciano cvv (vitis vinifera) to re-watering after a pre-veraison limiting water deficit. Funct Plant Biol 41(6):634-647

Pastenes C, Villalobos L, Ríos N, Reyes F, Turgeon R, Franck N (2014) Carbon partitioning to berries in water stressed grapevines: the role of active transport in leaves and fruits. Environ Exp Bot 107:154-166. https://doi.org/10.1016/j.envexpbot.2014.06.009

Roby G, Harbertson JF, Adams DA, Matthews MA (2004) Berry size and vine water deficits as factors in winegrape composition: anthocyanins and tannins. Aust J Grape Wine Res 10:100-107. https://doi.org/10.1111/j.1755-0238.2004.tb00012.x

Rogiers SY, Smith JA, White R, Keller M, Holzapfel BP, Virgona JM (2001) Vascular function in berries of Vitis vinifera L cv Shiraz. Aust J Grape Wine Res 7:47-51

Romero P, Fernández-Fernández JI, Martinez-Cutillas A (2010) Physiological thresholds for efficient regulated deficit-irrigation management in winegrapes grown under semiarid conditions. Am J Enol Vitic 61:300-312

Romero P, Botía P, Navarro JM (2018) Selecting rootstocks to improve vine performance and vineyard sustainability in deficit irrigated Monastrell grapevines under semiarid conditions. Agric Water Manage 209:73-93

Romero P, Botía P, del Amor F, Gil-Muñoz R, Flores P, Navarro JM (2019) Interactive effects of the rootstock and the deficit irrigation technique on wine composition, nutraceutical potential, aromatic profile, and sensory attributes under semiarid and water limiting conditions. Agric Water Manage 225:105733

Schultz HR, Matthews MA (1988) Vegetative growth distribution during water deficits in Vitis vinifera L. Aust J Plant Physiol 15:641-656

Shackel K (2011) A plant-based approach to deficit irrigation in trees and vines. HortScience 46(2):173-177

Smart DR, Carlisle E, Goebal M, Nunez BA (2005) Transverse hydraulic redistribution by a grapevine. Plant Cell Environ 28:157-166

Soar CJ, Dry PR, Loveys BR (2006) Scion photosynthesis and leaf gas exchange in Vitis vinifera L cv Shiraz: mediation of rootstock effects via xylem sap ABA. Aust J Grape Wine Res 12:82-96

Stoll M, Loveys B, Dry P (2000) Hormonal changes induced by partial rootzone drying of irrigated grapevine. J Exp Bot 51:1627-1634

Tombesi S, Nardini A, Farinelli D, Palliotti A (2014) Relationships between stomatal behaviour, xylem vulnerability to cavitation and leaf water relations in two cultivars of Vitis vinifera. Physiol Plantarum 152(3):453-464

Torres N, Yu R, Martinez-Lüscher J, Kostaki E, Kurtural SK (2021) Application of fractions of crop evapotranspiration affects carbon partitioning of grapevine differentially in a hot climate. Front Plant Sci 12:633600

Tramontini S, Vitali M, Centioni L, Schubert A, Lovisolo C (2013) Rootstock control of scion response to water stress in grapevine. Environ Exp Bot 93:20-26

Williams LE, Dokoozlian NK, Wample RL (1994) Grapevine. In: Schaffer B, Andersen PC (eds) Handbook of environmental physiology of fruit crops, volume I temperate crops. CRC Press, Boca Raton, pp 85-134

Winkel T, Rambal S (1993) Influence of water stress in grapevines growing in fields: from leaf to whole plant level. Aust J Plant Physiol 20:143-157

Publisher's Note Springer Nature remains neutral with regard to jurisdictional claims in published maps and institutional affiliations. 